\title{
COMPARATIVE FOLIAR MICROMORPHOLOGICAL STUDIES OF IN VITRO AND FIELD TRANSFERRED PLANTS OF MORINDA CITRIFOLIA
}

\author{
M. S. SHeKhaWAT ${ }^{1}$ and M. MANOKARI ${ }^{2}$ \\ ${ }^{1}$ Plant Science Department, MGGAC, Mahe, Puducherry, India; E-mail: smahipal3@gmail.com \\ ${ }^{2}$ Kanchi Mamunivar Centre for Postgraduate Studies, Puducherry, India \\ E-mail:manokari01@gmail.com
}

(Received 24 November, 2016; Accepted 27 April, 2017)

\begin{abstract}
Micromorphological studies revealed the developmental changes in micropropagated plants of Morinda citrifolia L. from in vitro conditions to field environment. The lower relative humidity, higher light intensity and septic stressful conditions in the field environment could make gradual changes in the micropropagated plants so as to adapt the external environment. Arrested stomatal development, single guard cells and indistinct subsidiaries were observed in vitro with highest stomatal density $(52.0 \pm 0.11)$ obtained in the ambient in vitro environment. The development of tissues, epidermal ornamentation, efficient stomatal functionality and vein-islets numbers $(12.0 \pm 0.0)$ during in vivo transfer may help in acclimation of micropropagated plants under field conditions. Raphides were observed in the in vitro propagated as well as in vivo transferred plantlets. The gradual acclimatisation and ex vitro rooting technique increased the survival rate of plantlets in the field. The micromorphological changes resulting from in vitro to field environments are important to understand the development of tissues and adaptation of micropropagated plants, which could help in improvement in survivability during field trials.
\end{abstract}

Key words: acclimatisation, in vitro, in vivo, micromorphological studies, Morinda citrifolia

\section{INTRODUCTION}

Morinda citrifolia L. (Rubiaceae) commonly known as Indian mulberry or Noni is a small glabrous tree, grows up to $4-9 \mathrm{~m}$ height and it is a rich source of life supporting secondary metabolites like anthraquinones, phenolic compounds, alkaloids, organic acids etc. (Wang and Su 2001). It is widely used to treat broken bones, deep cuts, bruises, sores and wounds in Indian traditional systems of medicines (Rethinam and Sivaraman 2007). Noni was reported for its broad range of therapeutic values against cancer, arthritis, diabetes, asthma, and hypertension (Chan-Blanco et al. 2006). The plant possesses sig- 
nificant immune-enhancing effects, smooth muscle stimulatory activity, histaminergic, antibacterial, antiviral, antitubercular, anti-inflammatory, analgesic, antioxidant and hypotensive effects (Furusawa et al. 2003).

The in vitro culture technique in $M$. citrifolia could provide continuous supply of better source of elite plant to be used as standard material in the field of drug research as well as in manufacturing of drugs. The in vitro regeneration of $M$. citrifolia has been reported by many research groups (Shekhawat et al. 2015, Sreeranjini and Siril 2014). Success in micropropagation technology could be achieved by production of large number of true-to-type regenerates with high survival rate in the field conditions, high accumulation of secondary metabolites under in vitro culture and enhanced carbohydrate metabolism during ex vitro transfer (Sahay and Varma 2000).

The success of in vitro technology in plant propagation hindered due to the failure of the tissue culture raised plants under field conditions. The profound understanding of the altered foliar micromorphology during plant development due to various stresses is of immense importance in predicting and improving the survival rate of plantlets from in vitro culture conditions to the acclimatisation stages (Moyo et al. 2015, Pospisilova et al. 1999, Sahay and Varma 2000). Therefore, the aim of the present study was to understand the foliar developmental changes in $M$. citrifolia based on micromorphological features from in vitro to field environment. The study could help in the successful establishment of micropropagated plantlets of M. citrifolia.

\section{MATERIALS AND METHODS}

In vitro propagation of Morinda citrifolia - Cultures were established according to our earlier report on efficient micropropagation of $M$. citrifolia (Shekhawat et al. 2015). Briefly, the nodal segments from four-year-old healthy plants were cultured on MS medium (Murashige and Skoog 1962) supplemented with $4.0 \mathrm{mg} \mathrm{L}^{-1}$ 6-benzylaminopurine (BAP). The in vitro regenerated shoots with mother explants were subcultured on MS medium augmented with 2.0 $\mathrm{mg} \mathrm{L}^{-1} \mathrm{BAP}$ and $1.0 \mathrm{mg} \mathrm{L}^{-1}$ Kinetin (Kin). The cultures were incubated at $25 \pm 2$ ${ }^{\circ} \mathrm{C}$ temperature, $60-70 \%$ relative humidity (RH) and $40-50 \mu \mathrm{mol} \mathrm{m}^{-2} \mathrm{~s}^{-1}$ Spectral Flux Photons (SFP) light intensity under $12 \mathrm{~h} / \mathrm{d}$. The microshoots were rooted in vitro on half strength agar-gelled MS medium containing $1.0 \mathrm{mg}$ $\mathrm{L}^{-1}$ IBA (Indole-3 butyric acid). Ex vitro rooting was achieved by treating the shoots with $300 \mathrm{mg} \mathrm{L}^{-1}$ IBA for $5 \mathrm{~min}$. The regenerated plants were transferred to ecofriendly paper cups containing soilrite ${ }^{\circledR}$, moistened with $1 / 4$ th MS macrosalts solution, maintained in the greenhouse for 4 weeks and finally established in the field conditions (Fig. 1A-F).

Foliar micromorphological studies - Experiments were conducted to study the foliar micromorphological changes (leaf constants) during plant develop- 
mental processes from in vitro to field environments such as venation pattern, vein density (vein-islets and veinlet terminations), types of stomata, stomatal density, stomatal index, and raphide density of the leaves of plants developed in vitro after 4 th subculture in multiplication phase and field established plants (after 6th week). Randomly selected leaf specimens at different developmental stages under in vitro and the field conditions were used. Completely expanded entire leaf samples at third to seventh leaves from the base were used to investigate the surface microstructures on the adaxial and abaxial surfaces. The paradermal sections were prepared by standard method (Johansen 1940) for the observation of developmental changes in structure and functioning of the stomata, stomatal morphology and distribution of raphides.

To study the leaf architectural development (venation study), leaves required from each stages were excised and fixed primarily in formalin acetic acid ethanol (FAA, 1:1:3) solution. The fixed leaves were treated with $70 \%$ ethanol (v/v) to remove the chlorophyll (12-24 h) and bleached with 5\% (w/v) $\mathrm{NaOH}$ for 24-48 h. Thereafter, the leaf materials were rinsed in distilled water and allowed to remain in saturated chloral hydrate/sodium hypochlorite solution for $12 \mathrm{~h}$ (Sass 1940). The cleared leaves were used to study the developmental changes in venation pattern, vein density (vein-islets and veinlet terminations) and raphide density. The terminology adopted for stomatal
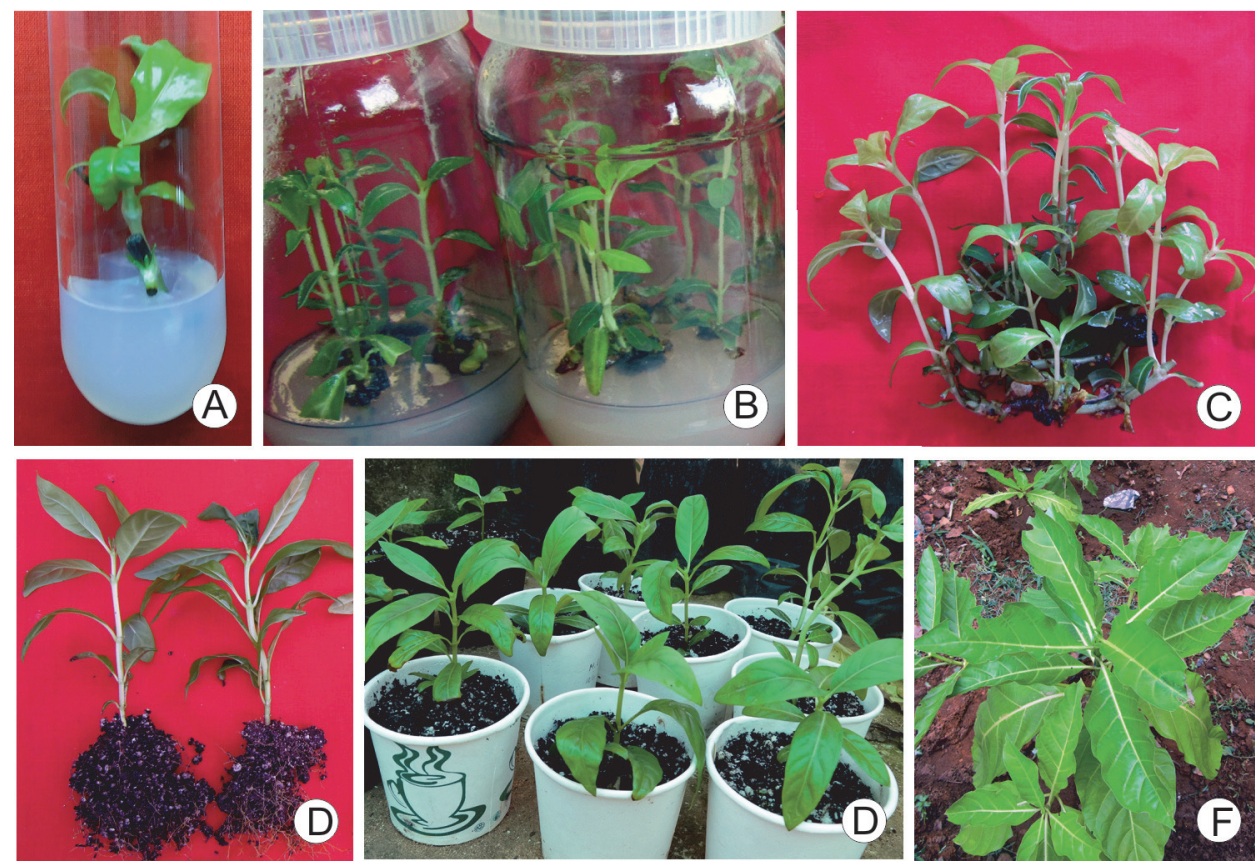

Fig. 1. Stages (A-F) in micropropagation of Morinda citrifolia 
study and venation pattern was of Hickey and Wolfe (1975), respectively. The intermediate types of stomata have been described by following the classification and terminology as suggested by Croxdale (2000). The materials were stained with $1 \%(\mathrm{v} / \mathrm{v})$ safranine (Loba chemie, India) aqueous solution for 4-8 min, rinsed carefully in distilled water to remove excess stain, mounted in water, examined under photomicroscope (Labomed iVu 3100, USA) and analysed using software Pixelpro.

Observations and data analysis - The experimental design consisted of two treatments (in vitro and field transferred plants) with ten replicates and repeated thrice. The data were subjected to analysis of variance and the significance of differences among mean values was carried out using Duncan's Multiple Range Test (DMRT) and reported as mean \pm standard error of the mean using SPSS software, version 16.0 (SPSS Inc., Chicago, USA). Values were regarded as significant at $P<0.05$.

\section{RESULTS AND DISCUSSION}

A proper understanding of the micromorpho-physiological characteristics and adjustments of in vitro raised plants during acclimatisation could be the critical and essential part of development of successful propagation protocol. The specific in vitro culture environments are responsible for the genetic and epigenetic characteristics, and altered physiology and anatomy (Jain 2001). The in vitro induced changes have to be repaired through subsequent acclimatisation before field transplantation of the plantlets (Pospisilova et al. 1999).

The present study was undertaken to examine the foliar micromorphological structures found across the developmental stages of leaves of in vitro propagated and field transferred plants of Morinda citrifolia. An examination of in vitro raised plants showed no morphological differences compared to the field transferred plants except in size of the organs. The plantlets possessed angular stem with broadly elliptic, glabrous shining leaves and suppressed peduncle. The leaves of in vitro raised shoots were small, lanceolate, glabrous and shining. The midrib and lateral veins were non-prominent and obscure. Gradual acclimatisation followed by field transplantation develops normal sized, lanceolate, glabrous, shining, bright green leaves, prominent midrib with 8-10 pairs of veins similar to its mother plants in nature.

\section{Epidermal and stomatal studies}

The paradermal sections of the leaves showed the presence of single layered epidermis on both the surfaces. The abaxial epidermal cells were loosely arranged, small in size, unorganised in shape, mostly rectangular or squar- 
ish with few undulations under in vitro culture conditions (Fig. 2A). Field emerged leaves presented distinct, tightly packed, highly wavy epidermal cells with sinuous anticlinal walls (Fig. 2B). The epidermal cells overlaying the veins (costal cells) were elongated, rectangular and polygonal in shape with straight anticlinal walls, and differed from epidermal undulations. Such differentiations were absent and obscure in the leaves of in vitro raised shoots. The development of thick and compact epidermal faces under higher light intensity in the field environment could reduce water loss by reflecting excessive radiation (Souza et al. 2010).

Leaves were hypostomatic and the abaxial epidermis had random distribution of stomata. The stomata were paracytic, both subsidiary cells were parallel to the long axis of the guard cells. The stomata consisted of biconvex lens shaped opening with crescent shaped guard cells and remained always opened irrespective of the time of examination under in vitro conditions (Fig. 2C). The stomata were closed, elliptic, functional and equal in size under the stressful environmental conditions in the field. Stomata displayed great structural diversity, the subsidiaries with different shapes and stained distinctly from the epidermal cells under in vitro conditions. Stomatal abnormalities such as arrested stomatal development, single guard cells and indistinct subsidiaries were observed in vitro, but these features were absent under field environment.
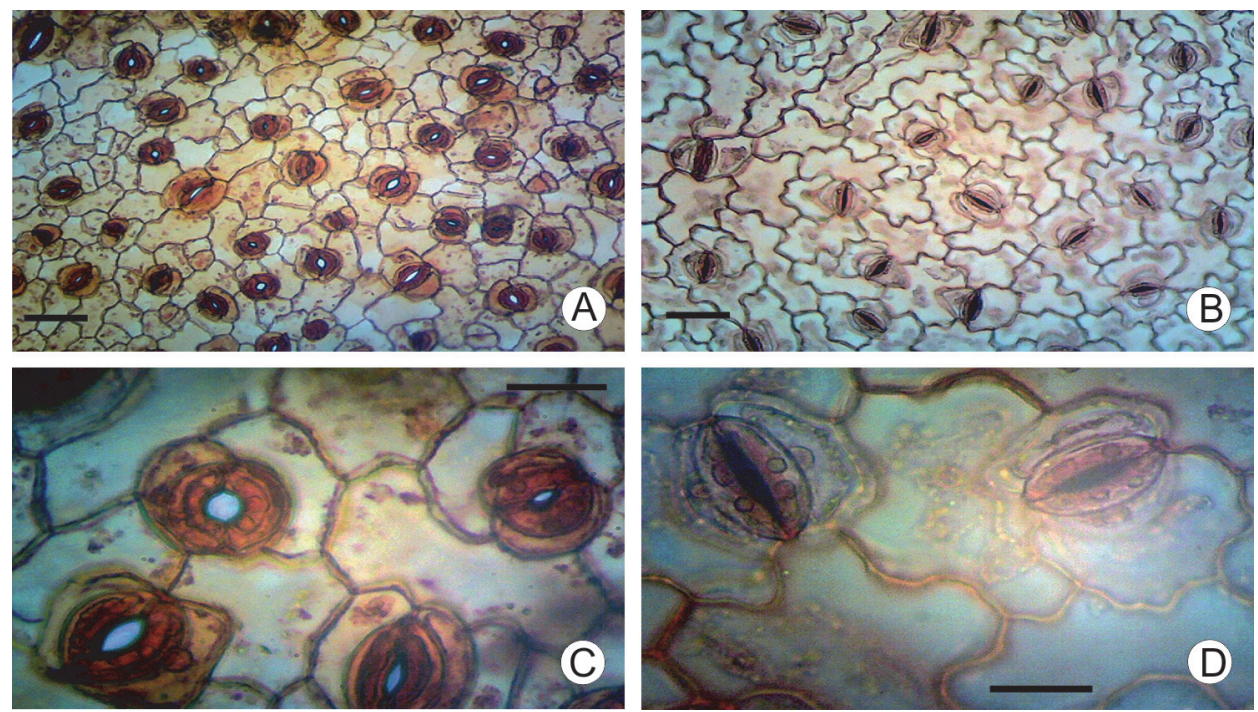

Fig. 2. $\mathrm{A}=$ Stomatal density in abaxial epidermis of in vitro raised leaves. $\mathrm{B}=$ Stomatal density in abaxial epidermis of leaves of field transferred plantlets. $C=$ Enlarged view of epidermal cells with stomata of in vitro leaves. $\mathrm{D}=$ Enlarged view of epidermal cells with stomata of field transferred leaves. Scale bar: A, B = $100 \mu \mathrm{m}, \mathrm{C}, \mathrm{D}=200 \mu \mathrm{m}$ 
Table 1

Stomatal density and stomatal index of leaves emerged in vitro and after transplantation of plants

\begin{tabular}{ccccc}
\hline Field No. & \multicolumn{2}{c}{ Stomatal density $($ mean \pm SD) } & \multicolumn{2}{c}{ Stomatal index $($ SI) $($ mean \pm SD) } \\
\cline { 2 - 5 } & In vitro & Field environment & In vitro & Field environment \\
\hline 1 & $52.7 \pm 0.11^{\mathrm{b}}$ & $18.5 \pm 0.24^{\mathrm{a}}$ & $19.8 \pm 0.16^{\mathrm{c}}$ & $15.7 \pm 0.00^{\mathrm{c}}$ \\
2 & $51.4 \pm 0.16^{\mathrm{a}}$ & $19.6 \pm 0.19^{\mathrm{c}}$ & $21.4 \pm 0.00^{\mathrm{d}}$ & $15.4 \pm 0.27^{\mathrm{bc}}$ \\
3 & $53.6 \pm 0.00^{\mathrm{c}}$ & $21.3 \pm 0.24^{\mathrm{e}}$ & $19.5 \pm 0.11^{\mathrm{bc}}$ & $14.9 \pm 0.14^{\mathrm{ab}}$ \\
4 & $52.2 \pm 0.10^{\mathrm{b}}$ & $21.0 \pm 0.11^{\mathrm{e}}$ & $19.0 \pm 0.17^{\mathrm{a}}$ & $15.5 \pm 0.19^{\mathrm{c}}$ \\
5 & $51.7 \pm 0.19^{\mathrm{ab}}$ & $21.8 \pm 0.26^{\mathrm{f}}$ & $19.2 \pm 0.12^{\mathrm{b}}$ & $15.3 \pm 0.14^{\mathrm{b}}$ \\
6 & $51.0 \pm 0.28^{\mathrm{a}}$ & $19.6 \pm 0.12^{\mathrm{c}}$ & $19.9 \pm 0.19^{\mathrm{c}}$ & $15.9 \pm 0.00^{\mathrm{d}}$ \\
7 & $53.3 \pm 0.20^{\mathrm{c}}$ & $20.0 \pm 0.19^{\mathrm{d}}$ & $21.2 \pm 0.25^{\mathrm{d}}$ & $14.5 \pm 0.14^{\mathrm{a}}$ \\
8 & $51.8 \pm 0.00^{\mathrm{ab}}$ & $19.2 \pm 0.15^{\mathrm{b}}$ & $20.0 \pm 0.10^{\mathrm{c}}$ & $14.7 \pm 0.22^{\mathrm{a}}$ \\
9 & $51.0 \pm 0.19^{\mathrm{a}}$ & $19.6 \pm 0.13^{\mathrm{c}}$ & $19.2 \pm 0.27^{\mathrm{b}}$ & $15.2 \pm 0.12^{\mathrm{b}}$ \\
10 & $51.3 \pm 0.22^{\mathrm{a}}$ & $19.4 \pm 0.17^{\mathrm{b}}$ & $21.4 \pm 0.00^{\mathrm{d}}$ & $15.9 \pm 0.19^{\mathrm{d}}$ \\
\hline Mean & $52.0 \pm 0.11$ & $20.0 \pm 0.39$ & $20.6 \pm 0.17$ & $15.3 \pm 0.13$
\end{tabular}

Mean values were analysed using SPSS software (ver. 16.0), the values represented in corresponding column followed by same letters are not significantly different according to Duncan's Multiple Range Test at $P<0.05$

The field transferred leaves showed characteristic structural arrangement of Rubiaceous stomata with distinguished subsidiaries and orderly sinuous epidermal cells (Fig. 2D). The stomatal structure and density are causative factors to excessive water loss in field grown plants (Chirinéa et al. 2012). Stomatal abnormalities under in vitro culture conditions were also reported in Elaeis guineensis (Luis et al. 2010), Ficus carica (Chirinéa et al. 2012) and Couroupita guianensis (Shekhawat and Manokari 2016a).

The position of the stomata varied and faced in all directions with in vitro leaves but the field transferred leaves exhibited certain order of distribution. The density of stomata in acclimatised plants decreased as the leaf matured in field grown plants. The stomatal density and stomatal index of in vitro emerged leaves were 52 and 20.6, reduced to 20 and 15.3 in field transferred plants (Table 1). The gradual acclimatisation and field transfer led to the development of leaf tissues with increased rate of photosynthesis. Shekhawat and Manokari $(2016 a, b)$ also reported that the stomatal density of in vitro regenerated Couroupita guianensis and Hemidesmus indicus plants changed with the physiological age of the leaf. Stomatal density and their functionality depend on the light intensity and $\mathrm{CO}_{2}$ concentrations of the environment where they survive (Yokota et al. 2007). 
We observed clear difference between costal and intercostals cells of field emerged leaves. The opened stomata with round guard cells under in vitro conditions were changed to the sunken elliptical normal stomata in field grown plants, which have also been reported in a number of plant species (Lodha et al. 2015). The abnormal feature of stomata, always in open conditions irrespective of the time is due to abnormal cell wall properties and imbalanced function of the protoplasts in the guard cells (Zeiger 1983).

\section{Study of venation and vein-islets}

Obscure venation and unorganised shaped vein-islets were observed for in vitro leaves. Reticulate venation, rhomboidal and rectangular vein-islets were reported in the field transferred leaves. The in vitro leaves possessed fewer vein-islets and veinlet terminations as compared to the field transferred plantlets (Fig. 3A). The number of vein-islets and veinlet terminations were increased, distinct and rhomboidal in shape under field conditions (Fig. 3B). The vein-islets of in vitro plants increased from 4.0 to 12.0 when transferred to the field (Table 2). The veinlet terminations of in vitro leaves were simple, ranging $0-1$ per islet, but higher number of veinlet terminations (1-2) developed in the leaves of field transferred plants. The increased veinlet terminations and closed venation pattern develops during the period of intercalary meristematic activity in the laminae leads to the maturation of leaves (Engard 1944). The prominent veins in the field transferred plants supports the development of vascular tissues and ensures translocation of minerals and nutrients (Miller 1990).

The gradual acclimatisation processes induce the innate ability of the plants to adapt stressful field environment. Marin (2003) reported that the evaluation of leaf anatomy would contribute to the understanding of the physiological and structural modifications for micropropagated plants and
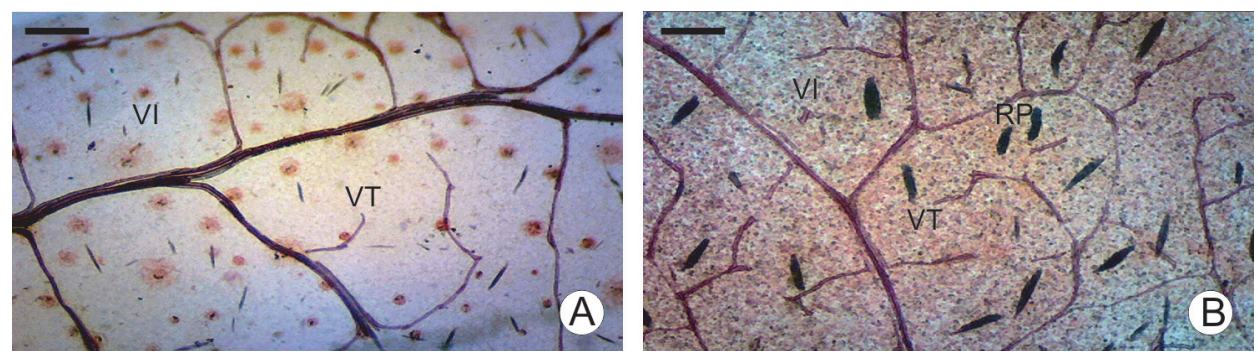

Fig. 3. $\mathrm{A}=$ Venation pattern and raphide density in leaves of in vitro raised shoots. $\mathrm{B}=\mathrm{De}-$ velopment of vein density and raphides after transplantation $(\mathrm{VI}=$ vein-islet, $\mathrm{VT}=$ veinlet termination, $\mathrm{RP}=$ raphides). Scale bar: $100 \mu \mathrm{m}$ 
Table 2

Differences in number of vein-islets and raphides density of in vitro and field transferred plants

\begin{tabular}{ccccc}
\hline Field No. & \multicolumn{2}{c}{ Number of vein-islets/mm $($ mean \pm SD $)$} & \multicolumn{2}{c}{ Raphide density $/ \mathrm{mm}^{2}(\mathrm{mean} \pm \mathrm{SD})$} \\
\cline { 2 - 5 } & $\begin{array}{c}\text { Under in vitro } \\
\text { environment }\end{array}$ & $\begin{array}{c}\text { Field transferred } \\
\text { plants }\end{array}$ & $\begin{array}{c}\text { Under in vitro } \\
\text { environment }\end{array}$ & $\begin{array}{c}\text { Field trans- } \\
\text { ferred plants }\end{array}$ \\
\hline 1 & $4.2 \pm 0.17^{\mathrm{e}}$ & $11.6 \pm 0.22^{\mathrm{b}}$ & $25.3 \pm 0.14^{\mathrm{f}}$ & $35.9 \pm 0.10^{\mathrm{b}}$ \\
2 & $3.9 \pm 0.24^{\mathrm{c}}$ & $11.2 \pm 0.19^{\mathrm{a}}$ & $24.0 \pm 0.11^{\mathrm{e}}$ & $36.2 \pm 0.15^{\mathrm{c}}$ \\
3 & $4.6 \pm 0.41^{\mathrm{g}}$ & $12.9 \pm 0.11^{\mathrm{f}}$ & $23.8 \pm 0.10^{\mathrm{d}}$ & $34.9 \pm 0.24^{\mathrm{a}}$ \\
4 & $3.3 \pm 0.33^{\mathrm{a}}$ & $12.4 \pm 0.25^{\mathrm{d}}$ & $24.5 \pm 0.00^{\mathrm{e}}$ & $35.7 \pm 0.13^{\mathrm{b}}$ \\
5 & $3.8 \pm 0.19^{\mathrm{bc}}$ & $11.7 \pm 0.14^{\mathrm{b}}$ & $20.0 \pm 0.12^{\mathrm{a}}$ & $36.4 \pm 0.10^{\mathrm{c}}$ \\
6 & $3.6 \pm 0.11^{\mathrm{b}}$ & $11.2 \pm 0.00^{\mathrm{a}}$ & $23.4 \pm 0.19^{\mathrm{d}}$ & $36.1 \pm 0.21^{\mathrm{c}}$ \\
7 & $4.4 \pm 0.00^{\mathrm{f}}$ & $11.9 \pm 0.21^{\mathrm{c}}$ & $21.8 \pm 0.26^{\mathrm{b}}$ & $35.3 \pm 0.19^{\mathrm{b}}$ \\
8 & $4.0 \pm 0.10^{\mathrm{d}}$ & $12.5 \pm 0.28^{\mathrm{d}}$ & $23.6 \pm 0.21^{\mathrm{d}}$ & $36.8 \pm 0.11^{\mathrm{c}}$ \\
9 & $4.2 \pm 0.23^{\mathrm{e}}$ & $12.0 \pm 0.16^{\mathrm{c}}$ & $22.0 \pm 0.14^{\mathrm{c}}$ & $36.4 \pm 0.00^{\mathrm{c}}$ \\
10 & $4.0 \pm 0.15^{\mathrm{d}}$ & $12.6 \pm 0.12^{\mathrm{e}}$ & $21.6 \pm 0.10^{\mathrm{b}}$ & $36.3 \pm 0.19^{\mathrm{c}}$ \\
\hline Mean & $4.0 \pm 0.26$ & $12.0 \pm 0.00$ & $23.0 \pm 0.13$ & $36.0 \pm 0.15$ \\
\hline
\end{tabular}

Mean values was analysed using SPSS software (ver. 16.0), the values represented in corresponding column followed by same letters are not significantly different according to Duncan's Multiple Range Test at $P<0.05$
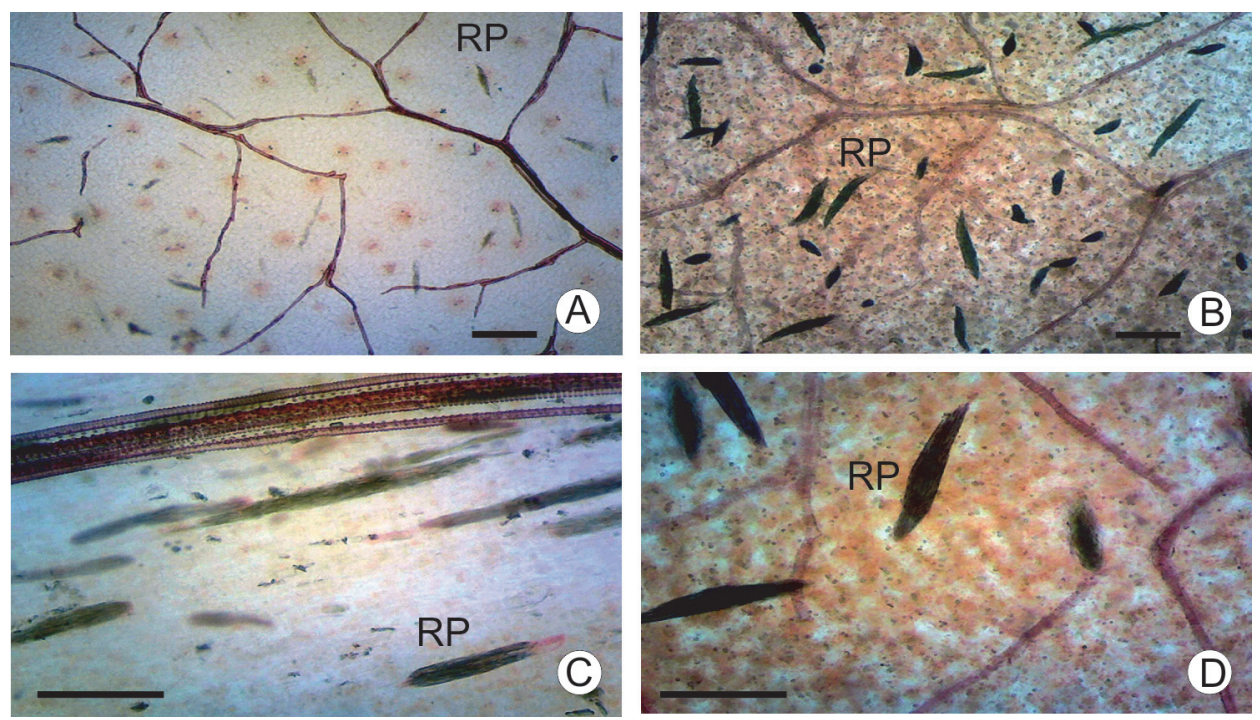

Fig. 4. A, C = Raphides and their morphology under in vitro conditions. B, D = Increase in raphide density and their morphology under field conditions $(\mathrm{RP}=$ raphides). Scale bar: $\mathrm{A}$, $\mathrm{B}=100 \mu \mathrm{m}, \mathrm{C}, \mathrm{D}=200 \mu \mathrm{m}$ 
give information applicable to the plant adaptation to the new environment. These changes increase the survivability of plants during acclimatisation.

\section{Development of crystals (raphides)}

The present investigation reveals the abundance of raphides in the in vitro as well as in vivo grown leaves of Morinda citrifolia. The leaf blade consisted of large cells comprised of solitary calcium oxalate styloid crystal bundles (Fig. 4A-B). The density of raphides visibly increased from 23 to 33 as the leaves mature in the field (Table 2). The leaves under in vitro conditions possessed underdeveloped raphides with blunted ends were developed with pointed ends in the field conditions (Fig. 4C-D). The increase in number of raphides under natural light conditions with incident solar radiation in the field environment might be due to their reactivity with oxalic acids and calcium accumulation, interference with increased metabolic, as well as physiological activities of regenerated plantlets of $M$. citrifolia.

It has been reported that the presence of crystals in higher plants enhanced the physical protection from herbivory and pathogens (Hanley et al. 2007). The results suggest that the environmental factors affect the formation of calcium oxalate crystals in M. citrifolia. The development of crystals occurs by the ran-
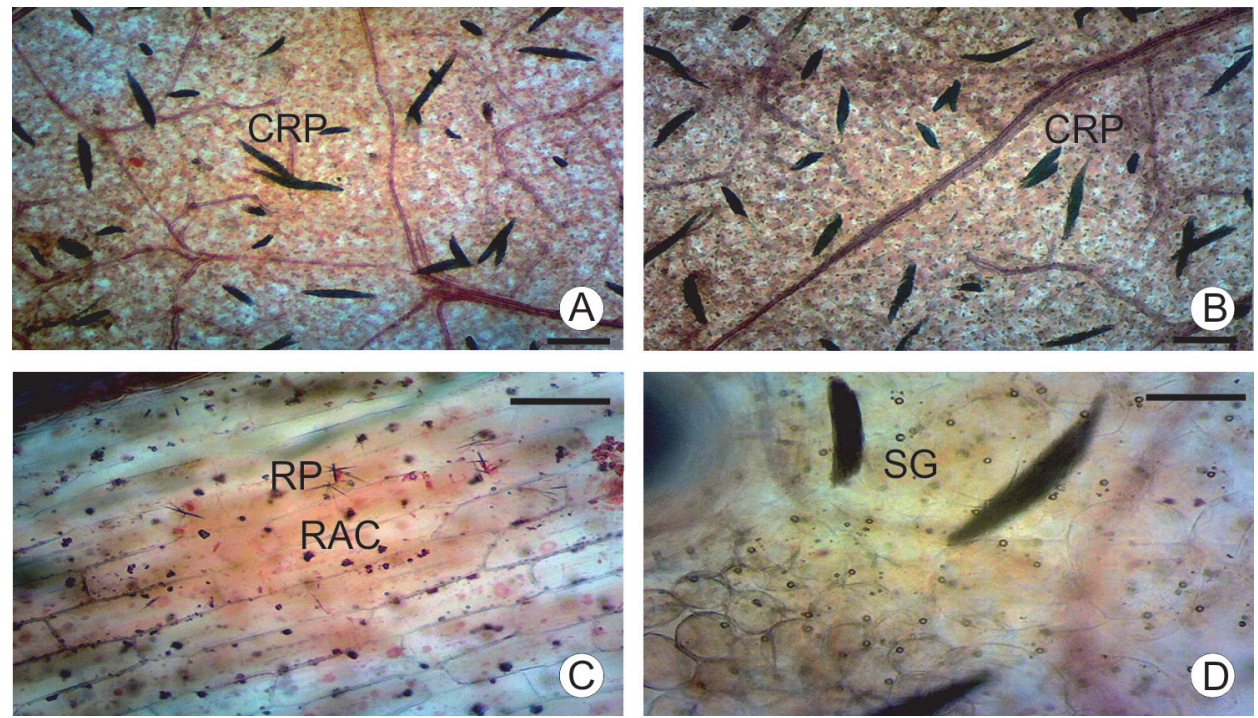

Fig. 5. Types of raphides and crystals developed in field transferred plants. A, B = Development of contiguous raphides in field transferred plants. $C=$ Raphides and rosette aggregate crystals in costal cells of field transferred plants. $\mathrm{D}=$ Development of starch grains in field transferred plants $(\mathrm{CRP}=$ contiguous raphides, $\mathrm{RP}=$ raphides, $\mathrm{RAC}=$ rosette aggregate crystals, $\mathrm{SG}=$ starch grains). Scale bar: $\mathrm{A}, \mathrm{B}=100 \mu \mathrm{m} ; \mathrm{C}, \mathrm{D}=200 \mu \mathrm{m}$ 
dom distribution of dissolved calcium and oxalate ions in the cells. The low concentration of dissolved ions causes other surrounding nuclei to dissolve, mediates the formation of one crystal per idioblast cell (Khan and Siddiqi 2014).

The field transferred plants develop contiguous raphides, and rosette aggregate calcium oxalate crystals along with the raphides in the costal cells (Fig. $5 \mathrm{~A}-\mathrm{C})$. Granular resins and starch grains were also observed in the mesophyll cells (Fig. 5D). Roonyamarai et al. (2011) and Shikerkar and Shrikanth (2015) also reported rosette aggregate crystals and raphides in the leaves of Morinda elliptica and M. citrifolia, respectively. The development of calcium oxalate crystals and their shapes were controlled genetically and influenced by light, temperature, soil, water and metal stresses (Kostman et al. 2001).

\section{CONCLUSIONS}

The comparative foliar micromorphological study of the in vitro grown and field transferred plants of Morinda citrifolia indicated the gradual development of epidermal ornamentation, stomatal functionality, raphide density and presence of rosette aggregate crystals. The stomatal density and stomatal index of in vitro emerged leaves were higher as compared to the field transferred plants. However, the numbers of vein-islets and veinlet terminations per area of in vitro plants increased when transferred to the field. The results could help in better understanding the survival possibility and successful transfer of in vitro produced plantlets to the natural soil conditions.

Acknowledgement - Authors are grateful to the University Grants Commission, New Delhi, Government of India for providing financial support as Major Research Project.

\section{REFERENCES}

Chan-Blanco, Y., Vaillant, F., Mercedes Perez, A., Reynes, M., Brilluet, J.-M. and Brat, P. (2006): The noni fruit (Morinda citrifolia L.): a review of agricultural research, nutritional and therapeutic properties. - J. Food Comp. Anal. 19: 645-654. https://doi. org/10.1016/j.jfca.2005.10.001

Chirinéa, C. F., Pasqual, M., De Araujo, A. G., Pereira, A. R. and De Castro, E. M. (2012): Acclimatization and leaf anatomy of micropropagated fig plantlets. - Rev. Bras. Fruticult. 34: 1180-1188. https://doi.org/10.1590/s0100-29452012000400027

Croxdale, J. L. (2000): Stomatal patterning in angiosperms. - Am. J. Bot. 87: 1069-1080. https://doi.org/10.2307/2656643

Engard, C. J. (1944): Organogenesis in Rubus. - Univ. Haivaii, Res. Pub. 21: 1-234.

Furusawa, E., Hirazumi, A., Story, S. and Jensen, J. (2003): Antitumor potential of a polysaccharide-rich substance from the fruit juice of Morinda citrifolia (Noni) on sarco- 
ma180 ascites tumor in mice. - Phytother. Res. 17: 1158-1164. https://doi.org/10.1002/ ptr.1307

Hanley, M. E., Lamont, B. B., Fairbanks, M. M. and Rafferty, C. M. (2007): Plant structural traits and their role in anti-herbivore defense. - Perspect. Plant Ecol. Evol. Syst. 8: 157178. https://doi.org/10.1016/j.ppees.2007.01.001

Hickey, L. J. and Wolfe, J. A. (1975): The bases of angiosperm phylogeny: vegetative morphology. - Ann. Miss. Bot. Gard. 62: 538-589. https://doi.org/10.2307/2395267

Jain, S. M. (2001): Tissue culture derived variation in crop improvement. - Euphytica 118: $153-166$.

Johansen, D. A. (1940): Plant microtechnique. - McGraw-Hill, New York, London, pp. 182197.

Khan, A. S. and Siddiqi, R. (2014): Environmental factors affect calcium oxalate crystals formation in Tradescantia pallida (Commelinaceae). - Pak. J. Bot. 46: 477-482.

Kostman, T. A., Tarlyn, N. M., Loewus, F. A. and Franceschi, V. R. (2001): Biosynthesis of L-ascorbic acid and conversion of carbons 1 and 2 of L-ascorbic acid to oxalic acid occurs within individual calcium oxalate crystal idioblasts. - Plant Physiol. 125: 634-640. https://doi.org/10.1104/pp.125.2.634

Lodha, D., Patel, A. K. and Shekhawat, N. S. (2015): A high-frequency in vitro multiplication, micromorphological studies and ex vitro rooting of Cadaba fruticosa (L.) Druce (Bahuguni): a multipurpose endangered medicinal shrub. - Physiol. Mol. Biol. Plants 21: 407-415. https://doi.org/10.1007/s12298-015-0310-6

Luis, Z. G., Bezerra, K. M. G. and Scherwinski-Pereira, J. E. (2010): Adaptability and leaf anatomical features in oil palm seedlings produced by embryo rescue and pre-germinated seeds. - Braz. J. Plant Physiol. 22: 209-215. https://doi.org/10.1590/s167704202010000300008

Marin, J. A. (2003): High survival rates during acclimatization of micropropagated fruit tree rootstocks by increasing exposures to low relative humidity. - Acta Hortic. 616: 139-142. https://doi.org/10.17660/actahortic.2003.616.13

Miller, I. M. (1990): Bacterial leaf nodule symbiosis. - Adv. Bot. Res. 17: 163-234. https://doi. org/10.1016/s0065-2296(08)60134-2

Moyo, M., Aremu, A. O. and Van Staden, J. (2015): Insights into the multifaceted application of microscopic techniques in plant tissue culture systems. - Planta 242: 773-790. https://doi.org/10.1007/s00425-015-2359-4

Murashige, T. and Skoog, F. (1962): A revised medium for rapid growth and bioassays with tobacco tissue culture. - Physiol. Plant. 15: 473-497. https://doi. org/10.1111/j.1399-3054.1962.tb08052.x

Pospisilova, J., Ticha, I., Kadleek, P., Haisel, D. and Plzakova, S. (1999): Acclimatization of micropropagated plants to ex vitro conditions. - Biol. Plant. 42: 481-497.

Rethinam, P. and Sivaraman, K. (2007): Noni (Morinda citrifolia L.). The miracle fruit - a holistic review. - Int. J. Noni Res. 2: 4-37.

Roonyamarai, W., Rungsihirunrat, K., Vipunngeun, N. and Ruangrungsi, N. (2011): Microscopic and molecular analyses of selected Morinda species in Thailand. - Asian J. Trad. Med. 6: 118-126.

Sahay, N. S. and Varma, A. (2000): A biological approach towards increasing the rates of survival of micropropagated plants. - Curr. Sci. 78: 126-129.

Sass, J. E. (1940): Elements of botanical microtechnique. - McGraw-Hill, New York, London, 222 pp.

Shekhawat, M. S. and Manokari, M. (2016a): In vitro propagation, micromorphological studies and ex vitro rooting of cannon ball tree (Couroupita guianensis Aubl.): a 
multipurpose threatened species. - Physiol. Mol. Biol. Plants 22: 131-142. https://doi. org/10.1007/s12298-015-0335-x

Shekhawat, M. S. and Manokari, M. (2016b): In vitro regeneration frequency, micro-morphological studies and ex vitro rooting of Hemidesmus indicus (L.) R. Br.: a multipotent endangered climber. - Ind. J. Plant Physiol. 21: 151-160. https://doi.org/10.1007/ s40502-016-0216-5

Shekhawat, M. S., Kannan, N., Manokari, M. and Ravindran, C. P. (2015): Enhanced micropropagation protocol of Morinda citrifolia L. through nodal explants. - J. Appl. Res. Med. Aromat. Plant 2: 174-181. https://doi.org/10.1016/j.jarmap.2015.06.002

Shikerkar, P. and Shrikanth, P. (2015): Pharmacognostic study of Achchhuka (Morinda citrifolia). - World J. Pharm. Pharma. Sci. 4: 641-649.

Souza, T. C., Magalhães, P. C., Pereira, F. J., Castro, E. M., Silva Júnior, J. M. and Parentoni, S. N. (2010): Leaf plasticity in successive selection cycles of 'Saracura' maize in response to periodic soil flooding. - Pesq. Agropec. Bras. 45: 16-24. https://doi. org/10.1590/s0100-204×2010000100003

Sreeranjini, S. and Siril, E. A. (2014): Field performance and genetic fidelity evaluation of micropropagated Morinda citrifolia L. - Indian J. Biotechnol. 13: 121-130.

Wang, M. Y. and Su, C. (2001): Cancer preventive effect of Morinda citrifolia (Noni). - Ann. N. Y. Acad. Sci. 952: 161-168.

Yokota, S., Karim, M. Z., Azad, M. A. K., Rahman, M. M., Eizawa, J., Saito, Y., Yshiguri, F., Iizuka, K., Yahara, S. and Yoshizawa, N. (2007): Histological observation of changes in leaf structure during successive micropropagation stages in Aralia elata and Phellodendron amurense. - Plant Biotech. 24: 221-226. https://doi.org/10.5511/plantbiotechnology.24.221

Zeiger, E. (1983): The biology of stomatal guard cells. - Annu. Rev. Plant Physiol. 34: 441475. https://doi.org/10.1146/annurev.pp.34.060183.002301 